Научная статья

УДК 81 '282.8

DOI 10.18101/2686-7095-2021-3-60-64

\title{
СВОДНЫЙ ДИАЛЕКТНЫЙ СЛОВАРЬ: НЕКОТОРЫЕ ПРОБЛЕМЫ СЕМАНТИЧЕСКОГО ОПИСАНИЯ
}

\author{
(C) Мызников Сергей Алексеевич \\ член-корреспондент РАН, доктор филологических наук, \\ главный научный сотрудник Центра ареальной лингвистики, \\ Институт славяноведения РАН \\ заведующий кафедрой уральских языков, фольклора и литературы, \\ Институт народов Севера РГПУ им. А. И. Герцена \\ заведующий отделом диалектной лексикографии и лингвогеографии русского языка, \\ Институт лингвистических исследований РАН \\ Россия, 119334, г. Москва, Ленинский пр-т, 32а \\ myznikovs@rambler.ru
}

\begin{abstract}
Аннотация. В работе представлен некоторый опыт работы над сводным диалектным словарем, работа над которым началась еще в 60-е гг. XX в. Рскрываются проблемы, возникающие при семантическом описании диалектных данных. Отмечается, что СРНГ является словарем дифференциального типа. Констатируется, что в ряде случаев точную толковательную формулу вывести было затруднительно, поскольку в источнике не имеется достаточно информации. На страницах словаря в 52-х томах остались без толкования свыше 4000 лексем. Рассматриваются проблемы выявления и выделения омонимов при разработке словарных статей, что нередко связано с отсутствием этимологических разработок лексикографируемых диалектных данных. Отмечается также, что в качестве материала для формирования словника использовались фольклорные произведения, из этого же источника черпались и цитаты, подтверждающие наличие слова в том или ином диалекте, однако лексикографическая разработка лексики фольклора нередко связана с серьезными трудностями.
\end{abstract}

Ключевые слова: словарь, диалектный, сводный, региональная семантика, толкование, говоры, омонимия, фольклор, значение.

\section{Для цитирования}

Мызников С. А. Сводный диалектный словарь: некоторые проблемы семантического описания // Вестник Бурятского государственного университета. Филология. 2021. Вып. 3. С. 60-64.

«Словарь русских народных говоров» представляет собой результат длительного труда профессиональных диалектологов, собирателей-любителей народного слова. В ходе работы над ним сменилось несколько поколений авторов-составителей и редакторов. Значительная часть материалов по лексике русских народных говоров хранится в основной картотеке Словарного отдела Института лингвистических исследований РАН. К настоящему времени вышли в свет 52 тома словаря. За годы работы над СРНГ был накоплен богатейший опыт семантических разработок диалектного материала, который вбирает в себя все русские диалекты. Поскольку работа над словарем близится к завершению, авторскому коллективу уже можно аналитически 
C. A. Мызников. Сводный диалектный словарь: некоторые проблемы семантического описания

осмыслять как достижения, так и недостатки, которые уже зафиксированы на страницах словаря.

В данной работе мы остановимся на некоторых проблемах семантического описания. Принципы описания слов в СРНГ изложены в «Проекте Словаря русских народных говоров» Ф. П. Филина [Филин, 1961]. Позже, по мере освоения диалектного материала, разработки технологии его исследования и описания в словаре, Инструкции для составителей были углублены и расширены [Сороколетов, Кузнецова, 1987].

СРНГ является словарем дифференциальным, причем этот принцип распространяется на всю структуру слова, что несколько осложняет (в случае разработки полисеманта) выстраивание исторически мотивированной семантической структуры слова.

Корректность и точность описания семантики в источниках.

К настоящему времени у нас появилась возможность рассматривать материалы СРНГ в широком контексте, т. е. обращаться непосредственно к первоисточникам лексикографических, этнографических, фольклорных и прочих источников. В этой связи мы стараемся прослеживать корректность подачи данных, которые помещаются в некоторые словари из других печатных источников. Такого рода внимание к материалам, которые обычно дистантны по времени сбора, анализа и выхода в свет, позволяет нам более детально и корректно представлять датировку и географию толкуемой единицы.

В ряде случаев точную толковательную формулу вывести было затруднительно, поскольку в источнике не имеется достаточно информации, например:

Хро'нтик, м. Вид кулика. По-нашему он хронтиком зовется. Купин. Новосиб., 1979. Хотя, вероятно, речь идет о кроншнепе.

В 49-м томе СРНГ была начата работа по показу сложностей, возникающих при работе над словарным текстом, и выявлению неточностей, которые уже зафиксированы на страницах СРНГ. Например, в 13-м томе СРНГ представлена следующая словарная статья 10. Кара, ж. Деньги. Была у нас турецккая кара. Казакинекрасовцы, 1969. Дара-то пара, да в кармане-то кара. (Не имеет ни копейки). Лодейноп. Ленингр., 1933 [СРНГ, 13, с. 63]. Однако кара, в значении 'деньги' с пометой - Казаки-некрасовцы - отсутствует в первоисточнике. Причем с этой семантикой в нем представлены другие данные: па'ры, па'ра. 'деньги': Все деньги называли пары. Колькя парах зарабил? - A ты адивай дитей, карми, на тибе парах, на тибе материх [Сердюкова, 2005, с. 188]. Кроме того, лексема ка'ра, зафиксированная на территории Ленинградской области, в зоне прибалтийско-финского влияния, имеет значение 'дыра, отверстие' также представлена в значении деньги, исходя из ложно понятого контекста: Пара-то пара, да в кармане-то кара (Не имеет ни копейки) [Лодейноп. Ленингр., 1933]. На это и указывает примечание собирателя. Следует отметить и неисконный характер этих гетерогенных данных, представленных в одной словарной статье. Их можно сопоставить с турец. para 'деньги; монета', при болгар. пара́, макед. пара, серб., хорв. па̀ра из турецкого [ТРС, 1977, с. 711], при болгар. пара́, макед. пара, серб., хорв. па̀ра из турецкого [ТЮВЕ]; а также с вепс. kar 'яма, углубление, выемка' [СВЯ, с. 179].

Еще один пример некорректной подачи семантики: Воля́ ['дуга'] Заметчин. Пенз., 1945 [СРНГ, 5, с. 88]. В СРНГ некорректно дано значение, должно быть 'луга', при форме заголовочного слова во множественном числе.

Крайне важна работа по семантизации материала, которая в процессе лексикографической работы не всегда была возможна. На страницах словаря в 52 томах остались без толкования свыше 4000 единиц (в 52-м томе - 58 лексем и лексико- 
семантических вариантов). Это нередко связано с представлением фольклорных данных:

Худоплечка, ж. [Знач.?]. Била мене под печкою, Называла мене мать худоплечкою (частушка). Нижнедев. Ворон., 1893 [СРНГ, 52, с. 204].

В ряде этих случаев толкование вывести было затруднительно, поскольку в источнике не имеется достаточно информации, например:

Хурда'чить, несов., неперех. [Знач.?]. «Я те покажу хурдачить!» Обл., Колосов, 1877 [СРНГ, 52, с. 227].

Еще одной проблемой при разработке словарных статей является выявление омонимов, нередко это связано с отсутствием этимологических разработок лексикографируемых диалектных данных. В СРНГ представляется широкое понимание омонимии, когда выделяются как омонимы только гетерогенные единицы, а лексемы, имеющие значения в различных понятийно-тематических рядах, но гомогенного происхождения, подаются в словаре в иерархии значений. О трудностях, связанных с репрезентацией гомогенной омонимии в словарях, говорил Б. А. Ларин, отмечавший, что «нелегко бывает с полной уверенностью и обоснованностью разграничить слова с древней богатой многозначностью от омонимов распада. Составители областных словарей предпочитают расчленение на «ряд омонимов», избегая громоздких статей с развернутой полисемией, в которых необходимо бывает проявить и проницательность при раскрытии семантической филиации (всегда скольконибудь исторической) и сочетать точность формулировки каждого значения с единой пронизывающей смысловой доминантой, образующей логический стержень статьи» [Ларин, с. 264-265].

Исходя из сложности задач, которые неизбежно встретятся на пути авторов сводного «Словаря русских народных говоров» ввиду спорности признаков гомогенной омонимии Ф. П. Филин считал, что очевидным является лишь одно: нельзя смешивать и считать за одно слово омонимы гетерогенные [Филин, 1961, с. 38].

В одном случае (в 51-м томе СРНГ) мы отошли от традиции ввиду появления явной вторичной мотивировки на русской почве. Речь идет слове Ходя, 4-е значение которого «китаец, занимавшийся в России мелкой торговлей в разнос» исторически восходит к результатам китайского влияния. Рассматривается как заимствование из кит. hиојi 'приказчик (продавец)' [БАС, 17, с. 302]. Н. А. Мещерский в качестве источника приводит кит. хуань-дай 'торгуем-меняем' при наличии большого числа соответствий в тунгусо-маньчжурских языках: негидал. хода 'продавать', ходаји 'продавец', ороч. ходаси-худаси 'продавать', хода 'товар', удэг. худа 'товар', ульч. худа 'торговля', орок. худа 'товар', худачи 'продавать', нанайск. хода 'товар, торговля' [ССТМЯ, 1, с. 467-468; Мещерский, 1989, с. 144]. Еще одну версию предложил

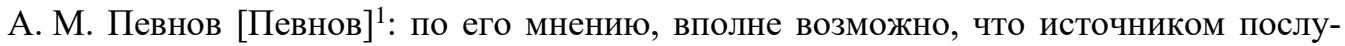
жило слово, обозначающее китайских эмигрантов: хуаця́о (трад. 華僑, упрощ. 华侨, пиньинь Нuáqiáo) - выходцы из Китая, проживающие в других странах, китайское хуаияо буквально означает «китайский эмигрант», «эмигрант из Китая» (хуа Китай, цяо - эмигрант, человек, проживающий вдали от родины).

Фонетико-морфологические диалектные приметы языка фольклора признаются всеми исследователями языка и стиля устного народного творчества. Фольклорные произведения использовались как материал для формирования словника не только СРНГ, но и других русских областных словарей. Из этого же источника черпались

${ }^{1}$ Певнов А. М. Устное сообщение. 
C. A. Мызников. Сводный диалектный словарь: некоторые проблемы семантического описания

и цитаты, подтверждающие наличие слова в том или ином диалекте. В СРНГ, например, лексика фольклора, не функционирующая в русском языке вне его произведений, включается в диалектные словари даже несмотря на то, что ее лексикографическая разработка нередко связана с серьезными трудностями, среди которых такие, как выделение заголовочной формы слова, осознание семантической сущности фольклорного слова для практической реализации ее в виде толкования и др. Именно фольклорный материал вызывал и вызывает критические замечания по поводу его лексикографической репрезентации, причем следует отметить, что слова с пометой фольк. довольно многочисленны в СРНГ - около 3,5 тыс. единиц.

В вышедших томах СРНГ представлено свыше 450 единиц, где толковательная формула дается в виде - эпитет кого-, чего-л., например: Типу'ха, ж. Фольк. Эпитет мухи. Муха буруха, за ногу типуха (сказка). Юрьев. Влад., 1910 [СРНГ, 44, с. 132].

Имеются материалы, когда довольно сложно разграничить эпитет как таковой и случаи дивергентной редупликации. Например: Ласко'тушка. Фольк. Эпитет ласточки [?]. Уж я лучше спрошу, беднушка, У косатой летной ластушки - Тая ластушкаласкотуика, Она летит ровнешенько (причит.). Север., 1960 [СРНГ, 16, с. 278].

Таким образом, работа над семантикой в сводном диалектном словаре, данные которого в большинстве своем представляют собой лексикографический конструкт с широким диалектным контекстом, непременно должна базироваться на обращении непосредственно к первоисточникам, этнографическим, фольклорным и прочим материалам.

\section{Литература}

1. Зайцева М. И., Муллонен М. И. Словарь вепсского языка. Ленинград: Наука. Ленингр. отд-ние, 1972. 746 с. Текст: непосредственный. (В тексте - СВЯ).

2. Ларин Б. А. Инструкция Псковского областного словаря // Псковские говоры: труды Псковской диалектологической конференции 1960 года. Псков, 1962. С 252-271. Текст: непосредственный.

3. Мещерский Н. А. Происхождение некоторых распространенных этнических апеллятивов в русской разговорной речи // Севернорусские говоры: межвузовский сборник / ответственный редактор А. С. Герд. Ленинград, 1989. Вып. 5. С. 143-146. Текст: непосредственный.

4. Сердюкова О. К. Словарь говора казаков-некрасовцев. Ростов-на-Дону: Изд-во Ростов. ун-та, 2005. 319 с. Текст: непосредственный.

5. Словарь русских народных говоров. Т. 1-52. Москва; Ленинград; СанктПетербург, 1965-2021. Текст: непосредственный. (В тексте - СРНГ).

6. Словарь современного русского литературного языка: в 17 т. Москва; Ленинград, 1948-1965 (В тексте - БАС).

7. Сороколетов Ф. П., Кузнецова О. Д. Принципы разработки вариантов слова в «Словаре русских народных говоров» // Словарь русских народных говоров. Ленинград: Наука, 1987. Вып. 22. С. 4-8. Текст: непосредственный.

8. Сравнительный словарь тунгусо-маньчжурских языков / ответственный редактор В. И. Цинциус. Ленинград: Наука. Ленингр. отд-ние, 1975-1977. Т. 1, 2. Текст: непосредственный. (В тексте - ССТМЯ).

9. Турецко-русский словарь. 48000 слов / А. Н. Баскаков, Н. П. Голубева, А. А. Кямилева, К. М. Любимов, Ф. А. Салимзянэва, Р. Р. Юсипова. Москва: Русский язык, 1977. 966 с. Текст: непосредственный. (В тексте - ТРС).

10. Тюркизмы в языках Юго-Восточной Европы (опыт сводного описания историколексикологических и этимологических данных / А. Х. Гирфанова, Ю. А. Лопашов, 
С. Петрович, Н. Л. Сухачев; под общей редакцией Н. Л. Сухачева (Рукопись). Текст: непосредственный. (В тексте - ТЮВЕ).

11. Филин Ф. П. Проект «Словаря русских народных говоров». Москва; Ленинград: Изд-во АН СССР, 1961. 198 с. Текст: непосредственный.

Статья поступила в редакцию 19.09.2021; одобрена после рецензирования 15.10.2021; принята к публикации 29.10.2021.

\section{CONSOLIDATED DIALECT DICTIONARY: SOME PROBLEMS OF SEMANTIC DESCRIPTION}

Sergey A. Myznikov

Corresponding Member of the Russian Academy of Sciences, Dr. Sci. (Phil.),

Chief Researcher of the Center for Areal Linguistics,

Institute of Slavic Studies RAS,

Head of Uralian Languages, Folklore and Literature Department,

Institute of the Nationalities of the North, Herzen Russian State Pedagogical University,

Head of Department of Dialectal Lexicography and Linguogeography

of the Russian Language,

Institute for Linguistic Research RAS

32a Leninsky Prospect, Moscow 119334, Russia

myznikovs@ rambler.ru

Abstract. The article presents some experience of working on a consolidated dialect dictionary, started from the 1960s. We have revealed the problems arising in the semantic description of dialect data. It is noted that the Dictionary of Russian Folk Dialects is a differential type dictionary. In a number of cases it was difficult to derive an exact interpretative formula, since there was no enough information in the source. More than 4,000 lexemes were left without interpretation on the pages of the dictionary in 52 volumes. We have considered the problems of identifying and highlighting homonyms dictionary entries, which are often associated with the lack of etymological developments of lexicographed dialect data. It is also noted that folklore works were used as material for the vocabulary, and quotes confirming the presence of a word in a particular dialect were also drawn from the same source, however the lexicographic development of the vocabulary of folklore encounters serious difficulties.

Keywords: dictionary, dialectal, consolidated, regional semantics, interpretation, dialects, homonymy, folklore, meaning.

For citation

Myznikov S. A. Consolidated Dialect Dictionary: Some Problems of Semantic Description // Bulletin of Buryat State University. Philology. 2021; 3: 60-64.

The article was submitted 19.09.2021; approved after reviewing 15.10.2021; accepted for publication 29.10.2021. 